Darja Senčur Peček*

\title{
THE SELF-EMPLOYED, ECONOMICALLY DEPENDENT PERSONS OR EMPLOYEES?
}

\section{Introduction}

Labour law traditionally protects employees, i.e. persons who perform work within the framework of an employment relationship. The main characteristic of employment relationship was (and still is) organisational integration of the person who carries out work in relation to the other contractual party, which allows the latter (employer) to direct and supervise the work. The employee does not look for opportunities in the market, but only works for the employer, is not in charge of the business, but instead undertakes to perform a specific job (part of the business), under the direction and supervision of the employer. As the weaker party in this relationship, the employee may not be able to ensure adequate regulation of their rights and obligations under the contract alone; therefore, labour legislation provides him with minimum rights, while additional rights may be agreed upon in collective agreements.

Unlike employees, the self-employed are persons who operate independently in the market, perform work on their own account, possibly for a number of contracting authorities, relationships with whom are regulated by civil or commercial contracts. They are thus subjects to the rules of corporate law, law of obligations, or commercial law, with labour law mainly applicable if they are also employers (if they employ workers).

Currently, an increasing number of persons carry out their work on a self-employed basis, i.e. without the employment relationship, however, not all of them

* Ph.D., Associate Professor at the Faculty of Law, University of Maribor, Faculty of Law, Labour Law Chair, 2000, Maribor, Mladinska 9, Slovenia. 
perform their work in the market, at their own risk and independently. In order for labour law to ensure protection for every person who carries out their work in dependant relationships and is in need of protection, it must also deal with the issue of distinction between employees and self-employeds, and determine who should be protected by labour law (in full or in part) ${ }^{1}$.

The fact is that it is not always easy to distinguish between employees and self-employeds. This is so because between a typical employment relationship and a typical relationship between two independent contractors there is a range of relationships where elements of the employment relationship are not explicitly expressed, or where elements of both relationships are intertwined. This is a socalled grey area between labour law and commercial $\mathrm{law}^{2}$ which is ever increasing.

This grey area also includes those economically dependent persons who are self-employed, but are also in need of protection due to their economic dependence on the contracting partner (client), similarly to employees.

A special category ${ }^{3}$ consists of persons who only appear to be self-employed, but actually carry out their work in a relationship where elements of employment relationship are present. These persons must be fully protected by labour law.

This article starts with a discussion of the concept of a self-employed person, different categories of self-employeds and their legal status. It then contemplates economically dependent persons, their definition and legal protection. Special emphasis is put on the problems of false self-employment and on a solution of this issue.

\section{The self-employed and their legal status}

The intention of labour law is to protect employees as the weaker party in the employment relationship. Labour legislation (and case law in some jurisdictions), therefore, provides a definition of an employee or an employment relationship, or sets out certain criteria that a person must meet to be considered an

${ }^{1}$ In this respect, see: Thematic Report 2009, Characteristics of the Employment Relationship, European Network of Legal Experts in the field of Labour Law, 2009; G. Davidov, B. Langille (ed.), Boundaries and Frontiers of Labour Law, Hart Publishing, 2006. See also: D. Senčur Peček, Komu zagotavljati delovnopravno varstvo, Podjetje in delo, 6-7/2007, p. 1223-1237.

2 See Green Paper: Modernising labour law to meet the challenges of the 21st century, COM (2006), 708 final, p. 11; A. Perulli, Economically dependent/quasi subordinate (parasubordinate) employment: legal, social and economic aspects, a study prepared for the European Commission, Brussels 2003, p. 15; E. Sanchez Torres, Self-employed Worker: The Spanish Law on Dependent Self-employed Workers: A New Evolution in Labor Law, "Comparative Labor Law \& Policy Journal" 2010, Vol. 31, No. 2, p. 3.

3 Which, according to some, also falls in a grey area, or is even described as a primary grey area. See: A. Perulli, op. cit., p. 15; E. Sanchez Torres, op. cit., p. 3. 
employee ${ }^{4}$. A person who does not meet these criteria, from the perspective of labour law, is not considered an employee, but a self-employed. The self-employed are therefore negatively defined ${ }^{5}$, or are defined in a residual manner ${ }^{6}$.

The category of self-employment, therefore, includes all contractual relationships ${ }^{7}$ that do not meet the criteria applicable to the employment relationship. In Slovenian legal system this pertains to any relationships that do not fulfil the criteria of Article 4 of the Employment Relationships Act (Zakon o delovnih razmerjih, ZDR-1) ${ }^{8}$.

From the perspective of labour law the distinction or definition of self-employment is important, since self-employeds are not granted the rights available to employees. No less important are the definitions of self-employment in the field of social insurance, as they decide whether and to what extent such persons are included in the social insurance system, and in the area of taxation, where they determine the manner of taxation of such persons. For specific groups of self-employeds the legislation also regulates the conditions on which they can run their businesses (for example, for sole traders, for certain freelance professions).

The definitions of self-employment in the various fields of law in different legal systems (sometimes even within a single legal system) differ from one another ${ }^{9}$. Nevertheless, it is possible to highlight the key characteristics of self-employment (investment of one's own capital, autonomy on the labour market, control over one's own work, and responsibility for the work done and for employment of workers) and to identify basic groups within the broad category of the self-employed ${ }^{10}$.

${ }^{4}$ For more on the concept of the employment relationship, see: R. Rebhahn, Der Arbeitnehmerbegriff in vergleichender Perspektive, „Recht der Arbeit“, 3/2009, Thematic Report 2009, Characteristics of the Employment Relationship, European Network of Legal Experts in the field of Labour Law, 2009.

5 See: A. Perulli, op. cit., p. 7.

6 R. Pedersini, D. Coletto, Self-employed workers: industrial relations and working conditions, European Foundation for the Improvement of Living and Working Conditions, Dublin 2010, p. 13.

7 In addition to the work contract (locatio operis), these are also supply services, agency work, pursuit of specific professions, as well as franchising, engineering, factoring, leasing, management, transfer of know-how, production and supply of software. See: A. Perulli, op. cit., p. 8.

8 Official Gazette of RS, No. 21/2013. The ZDR-1 defines the employment relationship in Article 4 as "a relationship between the employee and the employer, whereby the employee is voluntarily included in the employer's organised working process, in which he in return for remuneration continuously carries out work in person according to the instructions and under the control of the employer".

9 The absence of a clear national definition was also emphasised by the European Parliament in its resolution, where it additionally stressed that it increases the risk of false (apparent) self-employment. See: the European Parliament resolution of 14 January on social protection for all, including self-employed workers, 2013/2111 (INI), paragraph 28.

${ }_{10}$ In the research conducted by R. Pedersini, D. Coletto (op. cit., p. 15), the following groups were specified: 
It can be observed that in addition to the traditional forms (sole traders, craftsmen, independent professions, farmers), for which legislations set strict conditions, some new forms, too, qualify among the self-employed. In particular, this applies to professions that are not required to fulfil any special conditions (the new self-employed). These include, on the one hand, highly-educated professionals (graphic designers, web services providers, entertainment industry professionals, computer engineers, various consultants), who often are well-paid freelancers. On the other hand, there are self-employeds with low level of education, who work in construction, transport and similar industries, and are underpaid and unprotected, and not infrequently are disguised employees ${ }^{11}$. The new self-employed are thus both those who have acquired this status at their own discretion, because of tax advantages, greater freedom at work, or market advantages, and those who opted for it because they had no other choice - because, for example, the employer proposed business cooperation to a former employee ${ }^{12}$.

The second observation refers to the distinction between self-employed employers (self-employeds who employ workers) and self-employeds who carry out their work alone and do not employ workers. This division has been adopted in their statistics by both the Eurostat and the ILO, as well as by some legislations (e.g. in regard to taxation) ${ }^{13}$. Self-employed employers have a status similar to other employers (corporations and other legal entities) in regard to the performance of work; however, for the self-employed who carry out work themselves, their status can hardly be distinguished from that of employees. Among the self-employed who perform their work themselves we can identify both those persons who are actually independent in the market, and those who are economically dependent on a single client, as well as those who, for meeting the criteria for the employment relationship, are actually employees.

- Sole traders who carry out their activities with help of employees;

- Traditional independent professions (freelance professionals) who need to fulfil certain conditions, exams, enter into register, are bound by codes of their professional associations (lawyers, doctors) in order to carry out their professions;

- Craftsmen, traders and farmers (traditional forms of self-employment), who often involve family members, sometimes even a small number of employees, in their work;

- Self-employed persons in activities that require education or training, but are not part of regulated professions (the so-called new independent professions or new professionals);

- Self-employed persons in activities that do not require special training, who perform their work without employees, with occasional help from family members.

11 See: R. Pedersini, D. Coletto, op. cit., p. 1; also R. Pedersini, 'Economically dependent workers', employment law and industrial relations, European industrial relations observatory online, 2002, p. 21.

12 See also: A. Baldassarini, Boundary between self-employment and vulnerable work, informal contracts and undeclared work, Thematic Review Seminar on "Promoting entrepreneurship and self-employment across Europe", $8^{\text {th }}-9^{\text {th }}$ November 2010, p. 8.

13 R. Pedersini, D. Coletto, op. cit., p. 13, 19. 
According to the Eurostat ${ }^{14}$, the self-employed accounted for $15.2 \%$ of the active working population in the EU in $2012^{15}$. The highest proportion of the self-employed was found in Greece (31.9\%), Italy (23.4\%), Portugal (21.1\%), and Romania (20.1\%), while the lowest was observed in Estonia (8.4\%), Luxembourg (8.1\%), Denmark (8.9\%), and Lithuania (9.7\%). In Slovenia, this share was $12.2 \%$.

Only $28.3 \%$ of the self-employed in the EU (or $28 \%$ in Slovenia) employed workers, which means that the remaining self-employeds (almost three quarters) carried out their work themselves ${ }^{16}$. Most of the self-employed are active in market services (46.1\% in the EU, 37.6\% in Slovenia).

The findings of the Statistical Office of the Republic of Slovenia (RS) ${ }^{17}$ clearly demonstrate that self-employment has long been an established form of work in Slovenia. After the country regained independence the number of the self-employed increased significantly. In 1993, the share of the self-employed among all actively working persons was just over $12 \%$. After the initial increase in the number of the self-employed (mainly new local shopkeepers), the proportion of the self-employed decreased until 2009, but has once again increased in recent years. In 2010, among all the actively working persons in Slovenia, 12.4\% were self-employed. The Statistical Office noted that the increase in the number of the self-employed was affected by the Employment Service of Slovenia and its programme of subsidies for new self-employeds (which was launched in this period), and even more by new forms of employment with employers. The Statistical Office of the RS observed that "they usually prefer to employ someone who has a status of a sole trader, rather than enter into an employment relationship with an employee. This method of recruitment allows employers to suspend cooperation with the self-employed faster, while having fewer obligations at the same time in terms of breaks, vacations, education, etc."

International institutions and academics from different countries also emphasise the tendency for employers to avoid employing employees and thus avoid labour law protection through decentralisation of business processes, outsourcing, and public procurement as one of the reasons for the increased number of the self-employed ${ }^{18}$.

14 M. Teichgraber, European Union Labour Force Survey - Annual Results 2012, EUROSTAT, Statistics in focus, 14/2013.

15 All self-employed persons other than founders of legal entities (who are usually also employed by these legal entities, e.g. limited liability companies); hence sole traders and certain other categories only.

16 The data show that structure of the self-employed has changed in recent years, so that a greater proportion is represented by those who are not employers. The share of the self-employed who work only part-time has also increased. See: A. Baldassarini, op. cit., p. 5.

17 Kako prožen in varen je trg dela v Sloveniji?, Special Notice, Statistical Office of the RS, http://www.stat.si/novica_prikazi.aspx?id $=4375$ [30 ${ }^{\text {th }}$ November 2011].

18 See: R. Pedersini, D. Coletto, op. cit., p. 13. Opinion of the European Economic and Social Committee on 'Abuse of the status of self-employed' (own-initiative opinion), OJ C 161, $6^{\text {th }}$ June 2013, item 4.1; E. Sanches Torres, op. cit., p. 234; A. Baldassarini, op. cit., p. 5. 
Other reasons leading to the increase in the number of the self-employed (mainly due to the so-called new self-employeds) include increased service activities, new opportunities offered by information and communication technologies, emergence of new needs (related to ageing population), increased level of education in general population, increased share of women in the labour market, the need to include vulnerable groups in the labour market, and the ambition of some workers to more effectively balance their career and family life ${ }^{19}$.

Whether self-employment takes on its traditional form or comes as the socalled new self-employment, the self-employed (including those who perform their own work) are in a very different position from employees. They are not subject to the rules of labour law (in regard to minimum wages, protection against dismissal, etc.), since international documents and national legislation, as well as collective agreements, only regulate the status of employees. Exceptions can be found in the field of prohibition of discrimination, against which the self-employed are protected as well ${ }^{20}$, and occupational safety and health, where some international and national legal sources provide special rules for the self-employed that carry out their own work ${ }^{21}$.

In the field of social security, in the majority of European legislations it is possible to observe that the status of the self-employed is becoming similar to that of employees as regards their inclusion in the systems of compulsory social insurance ${ }^{22}$. Where such inclusion in the various systems of social insurance for the self-employed is (was) voluntary, and where the amount of the basis or contributions depends on the self-employed themselves, the self-employed observably enjoy a significantly lower level of social security in comparison to employees. Increasingly obvious is another aspect of the new self-employment, namely the fact that the self-employed often find themselves below the poverty line due to insufficient income (from which they must also pay contributions) ${ }^{23}$. The European Parliament addressed the problem of insufficient social security for the self-em-

19 See: Opinion of the European Economic and Social Committee on 'New trends in selfemployed work: the specific case of economically dependent self-employed work' (own-initiative opinion), OJ C 18, $19^{\text {th }}$ January 2011, item 3.1.1; A. Baldassarini, op. cit., p. 5.

${ }^{20}$ See for example: Directive 2010/41/EU of the European Parliament and of the Council of 7 July 2010 on the application of the principle of equal treatment between men and women engaged in an activity in a self-employed capacity (OJ L 180, $15^{\text {th }}$ July 2010, p. 1).

21 See: Council Recommendation 2003/134/EC of $18^{\text {th }}$ February 2003 on safety and health (minimum social protection) of all self-employed workers (OJ L 53, $28^{\text {th }}$ February 2003). See also: provisions of Articles 55 to 60 of the Zakon o varnosti in zdravju pri delu (Occupational Health and Safety Act), Official Gazette of RS, No. 43/2011 (ZVZD-1). See also: A. Perulli, op. cit., p. 118.

22 R. Pedersini, D. Coletto, op. cit., p. 21. Fears expressed by A. Supiot in his famous report of 1999 (p. 3) that the young educated people will want to avoid the inclusion in social insurance through these forms of work is therefore (now) without merits in these countries.

${ }^{23}$ In Slovenia, a quarter of the self-employed are below the poverty line. See: http://www.delo. si/novice/slovenija/samozaposlovanje-enterprising-in-siromastvo.html 
ployed in a Resolution on social protection for all, including the self-employed ${ }^{24}$, in which, among other things, (paragraph 32) Member States are called upon to develop necessary social protection in terms of retirement, disability, maternity/ paternity leave and unemployment, so that these rules will be better adapted to the needs of self-employed persons ${ }^{25}$.

In the Resolution (paragraph 34), the European Parliament also called upon Member States to inform persons wishing to acquire the self-employed status how this new status will affect their position in the light of social security and labour law, as well as of other rights and obligations that are related to their economic activity. It is questionable whether all prospective self-employeds are fully aware of the legal status of self-employed persons.

The actual status of the self-employed (their employment and working conditions) was to some extent illustrated by a research conducted by the European Foundation for the Improvement of Living and Working Conditions ${ }^{26}$. It was demonstrated that the self-employed ${ }^{27}$ often face low income, discontinuous work, insufficient qualifications, long and non-standard working hours, a high proportion of occupational accidents and health problems related to work. Furthermore, the authors of the research underlined the necessity of appropriate measures at both national and EU level (for example, adequate regulation of social protection, incentives for education, business support services ${ }^{28}$, and promotion of collective representation of the self-employed). The European Parliament petitioned for introduction of some of these measures (in terms of lifelong learning, self-organisation of the self-employed, and their possible inclusion in collective negotiations) as well ${ }^{29}$.

What all these measures have in common is that they aim to ensure minimum rights to all persons performing work, and not to equalise the status of the self-employed and employees. At the same time, regulation of the minimum status of the new self-employed and prevention of false self-employment can also be understood as a means to prevent distortions of competition and social dumping ${ }^{30}$.

$24\left(2013 / 2111(\right.$ INI) $), 14^{\text {th }}$ January 2014.

${ }^{25}$ Specific subsystem of social security, adapted to the needs of the self-employed, is for example already regulated in Spain (among other things, they are, for example, provided with a sick leave compensation from the first day of the sickness). See: R. Pedersini, D. Coletto, op. cit., p. 22-23.

26 R. Pedersini, D. Coletto, op. cit., p. 3, also p. 53-64.

27 The situation of course varies depending on whether the self-employed carry out their work themselves, or if they employ workers; on their activity, and similar.

28 The European Economic and Social Committee in its opinion of 2013 (item 2.9), for example, proposes to create service centres for the self-employed that would perform tasks for them, for example in relation to health and safety at work and to environmental protection.

29 See: Resolution, paragraphs 6, 11, 12, 35.

30 See: EESC Opinion 2013, Item 1.1, Resolution, item K of the preamble. 


\section{Economically dependent persons}

The existence of a category of persons who are not employees, but are nevertheless economically dependent on a sole client, and the ensuing necessity of providing them with certain social rights, was already recognised in 1999 by a well-known labour law theorist Alain Supiot in his report for the European Commission $^{31}$. In the ILO's materials, attention was also drawn to the phenomenon of such self-employed persons as electricians, plumbers, computer programmers, who eventually enter into permanent relationship with a sole client ${ }^{32}$.

In addition to the well established basic distinction between employees, who are subject to labour law protection, and the self-employed, who are not, a new group that is emerging is that of the so-called economically dependent persons ${ }^{33}$ who belong to the so-called grey area between the self-employed and employees $^{34}$. These persons are not employees (they do not meet the criterion of personal dependence), but nevertheless need particular protection due to their economic dependence.

In many legal systems (for example in Italy, the UK, Germany, Austria, the Netherlands, Portugal, Spain, Sweden) $)^{35}$, these economically dependent persons are provided with certain labour law protection, generally for being covered by certain norms of labour law ${ }^{36}$, if they meet the prescribed criteria: the negative criterion of absence of personal dependence, and the positive criterion of existence of economic dependency resulting from personal performance of work, non-appearance in the market, long-time cooperation with a sole contractual partner, and the fact that the income earned from this relationship is the only or main source of their entire income ${ }^{37}$.

With the implementation of the ZDR-1, Slovenia joined the countries that regulate the legal status of economically dependent persons. In doing so, both

31 Transformation of labour law and future of labour law in Europe, European Commission, 1999, p. 3.

32 See: Report V (1), International Labour Conference, 95 ${ }^{\text {th }}$ Session, 2006, p. 12; Meeting of Experts on Workers in Situation Needing Protection (The employment relationship: Scope), Basic technical document, p. 27.

33 In spite of different definitions of this category in each country (Arbeitnehmerähnliche Personen, parasubordinati), this term is widely used in Europe.

34 See: S. Perulli, op. cit., p. 15.

35 See: Thematic Report 2009, p. 34-37.

${ }^{36}$ In Germany, these provisions relate to annual leave, safety and health at work, protection against discrimination, collective negotiations and jurisdiction of labour courts; in the Netherlands such provisions relate to minimum wage and protection against dismissal; in Spain, among other things, such provisions relate to collective negotiations, annual leave and protection against dismissal.

37 R. Rebhahn, Arbeitnehmerähnliche Personen - Rechtsvergleich und Regelungsperspektive, „Recht der Arbeit“", 4/2009, p. 239; S. Perulli, op. cit., p. 98-100. 
theory ${ }^{38}$ and practice encountered a number of questions, while potential risks also became evident.

One major risk, also encountered in other legal systems that regulate economically dependent persons, is that regulation of economically dependent persons might encourage employers to engage in various business strategies (outsourcing) designed to force their employees to acquire the self-employed status and, at the same time, only provide them with protection available to economically dependent persons ${ }^{39}$.

This threat can be averted mainly by clearly defining the category of economically dependent persons and their distinction from other persons who perform work (the self-employed who are not economically dependent, employees) and by supervising the practical application of legal regulations. At this point, the following must be noted ${ }^{40}$ :

Economically dependent persons are self-employed persons, not employees, and should therefore be clearly distinguished from false self-employeds (disguised employees). If a self-employed, who is economically dependent, also meets the criterion of personal dependence (i.e. if their relationship with the client contains elements of employment relationship), such a person is to be considered an employee.

Only those (truly) self-employed persons who are economically dependent on their client can be classified among economically dependent persons. These include self-employeds who satisfy the criteria set by legislation for classification of economically dependent persons.

The above-described characteristics of this category of persons can also be inferred from the legal definition of economically dependent persons, both in Slovenian, and, for example, in Spanish law $^{41}$. Both countries list among the criteria those that separate economically dependent persons from employees, on the one hand, and those that distinguish them from other self-employeds (i.e. include them in the subgroup of economically dependent persons), on the other. The former are associated with the definition stating that economically dependent persons carry

38 Glej L. Tičar, Delovnopravno varstvo ekonomsko odvisnih oseb - novost ZDR-1, Delavci in delodajalci, 2-3/2013, p. 151-167; I. Knez, Novi Zakon o delovnih razmerjih - korak bližje k prožni varnosti, Pravna praksa, 10/2013, p. VI; T. Pustovrh Pirnat, Položaj ekonomsko odvisnih oseb v luči uveljavitve novega ZDR-1, Pravna praksa, 19/2013, p. 16-17; N. Weber, Tudi ekonomsko odvisne osebe do delovnega razmerja, Pravna praksa, 26/2013, p. 16-17.

39 See: EESC Opinion, 2011, item 5.1.1. See: M. R. Jayesh, M. Skapski, Reimagining the law of self-employment: a comparative perspective, "Hofstra Labor\&Employment Law Journal", 31/2013, p. 192; E. Sanchez Torres, op. cit., p. 234-235.

40 See also: EESC Opinion 2011, item 5.1.2; see also: A. Perulli, op. cit., p. 76-77.

${ }^{41}$ Spain has regulated contractual situation of self-employed persons, and especially economically dependent persons, in a special act in 2007. The European Economic and Social Committee labelled this act as the most complete definition of economically dependent work. See: the EESC Opinion 2011, item 4.1.2. 
out their work independently, on the basis of a civil law contract ${ }^{42}$, or the definition stating that these persons may not perform work that is identical to the work performed by employees of the client, that they should have their own production facilities and their own materials, if this is necessary for their activity, that they must carry out their services in accordance with their own organisational criteria (while a client may provide them with technical guidance), and receive the agreed payment that depends on the results of their activity, which was performed at their own risk $^{43}$. The latter are referred to by the definition stating that economically dependent persons carry out their work in person and do not employ workers ${ }^{44}$, and that they are economically dependent on the client (according to Slovenian legislation this means $80 \%$, and according to Spanish legislation $75 \%$ dependence on the income from the same client) ${ }^{45}$.

These legal criteria significantly narrow the group of potential economically dependent persons ${ }^{46}$, since they only include those persons who work on their own (without employees), essentially work for only one client, while working independently at the same time. As an example of such a person, it is possible to imagine a sole trader, who performs one of the secondary services for the client (such as cleaning), or who on the basis of a contract of business cooperation with a client repairs electrical appliances for consumers, while working independently, with his own resources, his own responsibility and is paid for successfully performed work.

A self-employed person who is no longer active in the market, but is economically dependent on contractual relationship with a sole or main client, is entitled to limited labour law protection, as defined by Article 214 of the ZDR-1, provided, however, that the client who must provide this protection is informed ${ }^{47}$. The reason is mainly to protect the self-employed from being one-sidedly granted disproportionally low payment by a sole client, and to prevent the latter from cancelling the contract without reason and without notice.

42 Stipulated in Article 213 of the ZDR-1.

43 See: E. Sanchez Torres, op. cit., p. 236-237.

44 See: Article 213 of the ZDR-1, as well as the Spanish act, which states that economically dependent persons may also not contractually transfer even part of their activities to a third party. See: E. Sanchez Torres, op. cit., p. 236.

${ }^{45}$ Ibid.

46 The same is the position of the Spanish theory, especially because of the criteria demanding that these persons perform work in person (without employees) and because owners of shops, workshops and offices, open to the public, and persons engaged in independent professions in partnership or in other forms of legal interaction with others are expressly excluded from the category of economically dependent persons. See: E. Sanchez Torres, op. cit., p. 237.

47 As provided by Article 214 of the ZDR-1, provisions of the ZDR-1 referring to prohibition of discrimination, assurance of minimum notice periods, prohibition of cancellation of a contract in cases of unfounded reasons for cancellation, assurance of payment for contractually agreed work appropriate for the type, scope and quality of the undertaken work (taking into consideration collective agreement and general acts binding the client and the obligation of payment of taxes and contribution) and enforcement of liability for damage shall apply to economically dependent persons. 
An economically dependent person is not an employee, and as such is not provided with other rights granted to employees by labour legislation and collective agreements. If, however, the contractual relationship between economically dependent persons and their sole or primary client develops or changes in such a way that it includes elements of the employment relationship, the status of an employee must be then granted to this person ${ }^{48}$.

\section{False self-employeds (disguised employment relationships)}

A disguised employment relationship occurs when the relationship between the employee and the employer outwardly appears different from what it actually is, with the aim to exclude or reduce protection guaranteed to employees, or to avoid payment of taxes and contributions ${ }^{49}$. It can be stated that in Slovenia the practice of disguising the true nature of the relationship is escalating. In the past, the problem mainly manifested itself in conclusion of fixed-term employment contracts in cases which actually called for indefinite employment contracts $^{50}$; in later cases employers posted job notifications, but concluded civillaw contracts (locatio conductio operis) instead of employment contracts with selected candidates, or concluded contracts of service, even though the manner in which the work was to be carried out would require an employment contract ${ }^{51}$. Recently, however, it is no longer uncommon to encounter job notifications where employers list the "sole trader" status as a condition to perform work in a vacant job position (or where they alternatively list conclusion of employment contract and cooperation with a sole trader). The intention is, therefore, to avoid labour law protection of a person who meets all the characteristics of an employee (all the elements of the employment relationship under Article 4 of the ZDR-1 are met), and to engage in "business cooperation" instead, since this person is formally self-employed (a so-called false self-employed). A similar situation often occurs in cases when the employer decides to outsource certain activities or parts

48 See: also EESC Opinion, 2011, item 5.1.3.

49 See: Report V (1), 2006, p. 12, Meeting of Experts, 2000, p. 26-27, which states that the most radical way of disguising an employment relationship consists of giving the relationship the appearance of a relationships of different legal nature - either civil, commercial or other. In addition, other forms of disguise are possible - permanent employment relationships are given the appearance of fixed-term employment contracts; in the case of tripartite relationships, the identity of the true employer is concealed (a person who is declared an employer is essentially only intermediary, while the true employer is thus free of any obligations towards employees).

${ }^{50}$ It has often been possible to observe among notifications of vacancies statements that the job is for a fixed time, with possibility of concluding a contract for indefinite period.

${ }^{51}$ According to the Report on the work of the Labour Inspectorate of the RS in 2012 (p. 58), 121 such cases were identified in 2012. 
there of to external contractors - former employees who carry out "their" work in practically the same way as before, except that they are no longer employees, but sole traders.

These phenomena are not new. The International Labour Organisation (ILO) has long been cautioning against the phenomena of false self-employment or disguised employment relationships in its documents, particularly in the ILO recommendation No. 198 of 2006 concerning the employment relationship and in the preparatory materials ${ }^{52}$. In the context of the European Union, this problem has already been addressed by the Green Paper entitled "Modernising labour law to meet the challenges of the 21 st century" ${ }^{\prime 3}$. Recent research suggests that this phenomenon is becoming more and more widespread ${ }^{54}$.

The European Parliament rightly points out that high levels of unemployment in many Member States, in connection with the existing pressure to reduce labour costs, bring about practices that facilitate further development and growth of false self-employment ${ }^{55}$.

As emphasised by the European Economic and Social Committee in its opinion on abuse of the self-employed status ${ }^{56}$, self-employment has cropped up in the most vulnerable sectors of the labour market ${ }^{57}$, where workers (also through various agencies) are hired as self-employed service providers, and no more as employees. Inexpensive work is available to employers for nothing more than payment of an invoice issued by a service provider. This situation, however, raises doubts about the actual status of the self-employed.

Forms of false self-employment are becoming increasingly sophisticated. In addition to sole traders (a status that can be very quickly and easily acquired) and founders of one-person companies, who perform their work themselves (in the same way as employees), another form of false self-employment can, for example, be a civil law company which, in addition to the manager, involves a number of uneducated persons (usually foreigners) who carry out work in the same way as employees ${ }^{58}$. In all these cases, a person who is seemingly self-employed, but de facto is an employee, is not guaranteed labour law protection, while the employer also shifts the burden of contributions and taxes onto him or her.

52 See: Report V (1), International Labour Conference, $95^{\text {th }}$ Session, 2006 (Report V (1), 2006), Report V (2A), International Labour Conference, 95 ${ }^{\text {th }}$ Session, 2006; Report V (2B), International Labour Conference, $95^{\text {th }}$ Session 2006.

53 Of 22 nd November 2006; COM (2006) 708 final.

${ }^{54}$ See: Self-employment in Europe, 2010, p. 29; see: R. Pedersini, D. Coletto, op. cit., p. 3, 64.

55 Resolution, item $\mathrm{M}$.

56 See: EESC Opinion, 2013, item 2.4.

${ }^{57}$ For example, in the construction industry. See: Y. Jorens, Self-employment and bogus self-employment in the European construction industry, A comparative study of 11 member states, European Federation of Building and Woodworkers, FIEC and European Commission.

58 See: Y. Jorens, op. cit., p. 18-19. 
All this calls for an urgent action against false self-employment, including strict enforcement of the existing regulations and development of new measures against these phenomena ${ }^{59}$. This is especially necessary in some sectors where this phenomenon is the most widespread ${ }^{60}$.

One condition for action against false self-employment is a suitable definition of the employment relationship. To this end, some countries have already complemented national regulations with additional criteria or (rebuttable) presumption of existence of employment relationship.

As an example of good practice, the European Economic and Social Committee ${ }^{61}$ mentioned Malta's legislation which dictates that a formally self-employed person is presumed to be an employee (and the person for whom services are provided is the employer), if at least five of the eight criteria are met in the performance of work ${ }^{62}$.

A similar (rebuttable) presumption was enshrined in the amendment to Belgian employment relationships act of 1st January 2013 with regard to four activities where the problem of false self-employment is the most severe (construction, security and surveillance, transport of persons and goods, cleaning services), while its application may also be extended to other activities in the future. Formally self-employed persons are presumed to be employees, if they meet five out of nine criteria ${ }^{63}$.

Although Slovenian legislation does not provide any similar presumptions of existence of employment relationship, I believe that the already mentioned (and other) criteria could serve as benchmarks for judicial practice and labour inspection when assessing the true nature of the relationship. Formally self-employed persons are in fact employees, if their position does not contain elements which are otherwise typical of self-employment (independence in decision-making and performance of work, own premises and work resources, responsibility for the performed work,

59 Resolution, paragraph 31, R. Pedersini, D. Coletto, op. cit., p. 3.

${ }^{60}$ See: EESC Opinion, 2011, item 1.

${ }^{61}$ See: EESC Opinion, 2013, item 4.3.

62 The criteria are as follows: he depends on one single person for whom the service is provided for at least $75 \%$ of his income over a period of one year; he depends on the person for whom the service is provided to determine what work is to be done and where and how the assigned work is to be carried out; he performs the work using equipment, tools or materials provided by the person for whom the service is provided; he is subject to a working time schedule or minimum work periods established by the person for whom the service is provided; he cannot sub-contract his work (to other individuals to substitute himself when carrying out work); he is integrated in the structure of the production process, the work organisation or the company's or other organisation's hierarchy; the person's activity is a core element in the organisation and pursuit of the objectives of the person for whom the service is provided, and he carries out similar tasks to existing employees, or (in the case when work is outsourced) he performs tasks similar to those formerly undertaken by employees. See: Opinion of the EESC, 2013, item 4.3.

${ }_{63}$ See: http://www.laga.be/newsroom/legal-news/Belgian\%20parliament\%20tightens\%20 legislation-towards-the-practice-of-false-self-employment, http://www.ey.com/BE/en/Newsroom/ News-releases/Tax-alert---Recent-developments-with-regard-to-anti-social-fraud-measures. 
carrying business risks, employment of workers), while the elements typical of employees (economic dependence on the client, personal performance of work, dependence on the client) are present, instead.

An important indication of existence of the employment relationship can be provision of services which fall within the core business of the client. Courts and labour inspectors should therefore pay particular attention to sole traders who work as chefs in restaurant, as cosmeticians in beauty salons and the like. The same can be derived from the second paragraph of Article 13 of the ZDR-1 which states that work may not be performed on the basis of civil law contracts (amongst which contracts of business cooperation with sole traders and other self-employed persons can also be included), if elements of employment relationship exist pursuant to Article 4 of the ZDR-1 and in connection with Article 22 of the ZDR-1 (i.e. when the work is carried out at systematised working positions - these are exactly the jobs that fall within the core business of the employer).

Another obvious indicator can be performance of work in the same manner as it is performed by employees of this client (when a sole trader performs work together with the employees of his "client"), or the fact that a sole trader performs services or work in the same manner and under the same conditions as he did before acquiring the self-employed status ${ }^{64}$ in employment relationship with the same "client" 65 .

The fact is that the labour court can only establish the true nature of the contractual relationship on the basis of a lawsuit which, due to the poor prospects as regards other forms of employment, false self-employeds often do not dare to file ${ }^{66}$. In this situation even greater importance is attached to the role of labour inspection which, if it identifies a violation of the second paragraph of Article 13 of the ZDR-1, can take action against the employer. In my opinion, strengthened activities of labour inspection in the area of prosecution of false self-employment could have positive effects.

\section{Conclusions}

Everyone has a right to be self-employed, and labour law does not interfere with this right. The self-employed benefit from the advantages of independent activity in the market and make their own decisions about their work.

${ }^{64}$ Which occurred due to outsourcing, i.e. due to a decision of the employer that certain secondary activities will no longer be carried out by the employees of this employer, but by the external contractors (former employees who became sole traders).

65 See also: Self-employment in Europe, 2010, p. 29.

${ }^{66}$ Some of these cases can be found - See for example a decision of the Higher Labour and Social Court in Slovenia in the case Pdp 558/2013 of $22^{\text {nd }}$ August 2013 and the judgment of the same court in the case Pdp 721/2012 of $5^{\text {th }}$ December 2012. 
When a business relationship between a self-employed and his/her contractual partner develops so that the self-employed does not appear in the market (anymore), but is economically dependent on the client, labour law in some legislations provides this economically dependent person with a certain level of protection. The category of economically dependent persons does not represent competition in relation to employment relationships, but rather extends certain level of protection to persons who are not employees.

Contractual cooperation with the self-employed must not constitute a form which would allow employers to deprive employees of labour law protection. This happens when employees are forced to carry out work as false (disguised) self-employeds. These sorts of practices urgently need to be stopped, however, to achieve this goal it takes to appropriately distinguish between employees and self-employeds, identify disguised employment relationships, and impose sanctions for abuse. 